\title{
An effective and simplified DO-stat control strategy for production of rabies glycoprotein in Pichia pastoris
}

\author{
L.D. Picotto ${ }^{\text {a, b, }{ }^{*} \text {, G.H. Sguazza }}{ }^{\text {b }}$, M.A. Tizzano ${ }^{\text {b }}$, C.M. Galosi ${ }^{\text {b, c }}$, S.F. Cavalitto ${ }^{\text {a, }}{ }^{\text {, }}$ \\ M.R. Pecoraro ${ }^{b}$ \\ a CINDEFI, CONICET, La Plata, Argentina \\ ${ }^{\mathrm{b}}$ Department of Virology, School of Veterinary Sciences, National University of La Plata, Buenos Aires, Argentina \\ ' Scientific Research Commission, Buenos Aires Province (CIC-PBA), Argentina \\ ${ }^{\mathrm{d}}$ Department of Biotechnology, School of Exact Sciences, National University of La Plata, Buenos Aires, Argentina
}

\section{A R T I C L E I N F O}

\section{Article history:}

Received 21 June 2016

Received in revised form

6 February 2017

Accepted 7 February 2017

Available online 9 February 2017

\section{Keywords:}

Pichia pastoris

DO-stat

Rabies virus

Glycoprotein

\begin{abstract}
A B S T R A C T
The glycoprotein (G-protein) of rabies virus is responsible for viral attachment to the host cell surface and induces virus neutralization antibodies. In the present study, the G-protein gene of rabies virus CVS strain was cloned, sequenced and expressed in the yeast, Pichia pastoris, as a secreted protein, using a simplified DO-stat control feeding strategy. This strategy involves the addition of methanol when the dissolved oxygen (DO) level rises above the setpoint avoiding methanol accumulation and oxygen limitation. The G-protein expression was evaluated by SDS-PAGE, ELISA, and western blot assays. Like native G-protein, the recombinant G-protein was found reactive when it was challenged against specific antibodies. The data indicate that the recombinant G-protein can be easily expressed and isolated, and may be useful as a safe source in the production of diagnostic kits and subunit vaccines to prevent rabies.
\end{abstract}

(C) 2017 Elsevier Inc. All rights reserved.

\section{Introduction}

Rabies is a serious disease which causes a fatal form of encephalomyelitis in humans and animals when treatment is not administered. The annual number of human deaths worldwide is estimated to be 59,000 [1]. Most of these occur in developing countries, where canine rabies is enzootic, and rabid dog bite is the most common mode of transmission [2]. The existence of large reservoirs of rabies virus in stray dogs and many wild animal species represents a serious problem for humans and domestic animals [3].

Although there is evidence that controlling dog rabies through vaccination programs and eliminating stray dogs can reduce the incidence of human rabies [4], exposure to rabid dogs causes more than $99 \%$ of human deaths by rabies [5].

The rabies virus belongs in the Lyssavirus genus within the Rhabdoviridae family. This virus has a single stranded ribonucleic acid (RNA) genome in the negative sense orientation which encodes five proteins in the following order: nucleoprotein,

\footnotetext{
* Corresponding author. CINDEFI, Facultad de Ciencias Exactas, 47 y 115, 1900, La Plata, Argentina.

E-mail address: lpicotto@fcv.unlp.edu.ar (L.D. Picotto).
}

phosphoprotein, matrix protein, G-protein, and RNA dependent RNA polymerase [6,7]. The G-protein, the only protein exposed on the surface of the viral particle, is involved in the binding to the cellular receptors, as well as the entry of the viral particle into the host cell. Structure of the G-protein (a type I transmembrane protein) consists of a cytoplasmic domain, a transmembrane domain, and an ectodomain exposed as trimers at the virus surface $[8,9]$.

The G-protein ectodomain stimulates neutralizing antibody production to protect vaccinated animals from rabies virus infection by inducing $\mathrm{T}$ lymphocytes and $\mathrm{T}$ helper cells [10-14]. Importantly, to stimulate immune protection by vaccination, glycosylation of the G-protein is needed [15-17]. Therefore, it is necessary to produce the G-protein in a eukaryotic host. In this way, we decided to express the rabies G-protein because it is the most antigenic and immunogenic protein in the rabies.

Vaccines are a useful tool in programs of health intervention. Production of rabies vaccines in cell cultures and in suckling mouse brains (also known as Fuenzalida-Palacios) [18] involves handling live virus and is expensive. Furthermore, Fuenzalida-Palacios vaccine often leads to neurological complications [19].

Yeasts have been successfully used to produce viral proteins $[20,21]$. The Pichia pastoris (P. pastoris) expression system was selected because it has several technical advantages, such as site- 
specific integration, high levels of protein expression, eukaryotic post-translational modifications [22], a good leader sequence for the secretion of recombinant protein in the medium, and it is relatively easy to scale-up.

The closed-loop feeding strategies rely on a measurement that is an indicator of the metabolic state of the culture. The dissolved oxygen (DO) concentration and $\mathrm{pH}$, in microbial fermentation are also key indicators of cellular physiology. The DO-stat control of nutrient feeding is based on the concept of DO rises (due to a reduction or cessation of oxygen consumption or respiration) upon nutrient limitation or depletion. The DO-stat control maintains the culture at a stationary DO level (the DO setpoint) by increasing the nutrient feed rate when DO rises above the setpoint and reducing the nutrient feed rate when DO drops below the setpoint. The DOstat strategy typically works well in defined media where nutrient depletion results in rapid DO rise.

In the present study, we describe the expression of the rabies Gprotein in a Mut ${ }^{+}$strain of P. Pastoris, GS115, during growth on methanol under control of the strongly induced AOX1 promoter. We also report the optimization of culture conditions for G-protein expression by means of a DO-stat feeding strategy. The DO-stat control feeding strategy used in this work involves the addition of methanol when the dissolved oxygen (DO) level rises above the setpoint. Therefore, this method avoids the methanol accumulation and oxygen limitation.

\section{Materials and methods}

\subsection{Strains, plasmids, and culture media}

Challenge virus standard (CVS-11) strain of rabies virus. Escherichia coli TOP10' strain, P. pastoris GS115 and pPIC9 expression vector from Invitrogen Co. (USA).

Yeast extract peptone media (YPD), buffered glycerol media (BMG), buffered methanol media (BMM), Luria Bertani plates containing $100 \mu \mathrm{g} / \mathrm{ml}$ ampicillin (LB-Amp), and minimal dextrose plates (MD) as described in Invitrogen Pichia expression kit (USA).

Synthetic medium (SM) containing glycerol $32 \mathrm{~g} / \mathrm{l} ; \mathrm{KH}_{2} \mathrm{PO}_{4} 20 \mathrm{~g} /$ l; $\mathrm{MgSO}_{4} \cdot 7 \mathrm{H}_{2} \mathrm{O} 2 \mathrm{~g} / \mathrm{l} ; \mathrm{CaCl}_{2} \cdot 2 \mathrm{H}_{2} \mathrm{O} 0,3 \mathrm{~g} / \mathrm{l} ;\left(\mathrm{NH}_{4}\right)_{2} \mathrm{SO}_{4} 15,7 \mathrm{~g} / \mathrm{l} ; 1 \mathrm{ml} / \mathrm{l}$ of $1000 \times$ vitamins solution (biotin $0.002 \mathrm{~g} / \mathrm{l}$; pantothenate calcium $0.4 \mathrm{~g} / \mathrm{l}$; acid folic $0.002 \mathrm{~g} / \mathrm{l}$; niacin $0.4 \mathrm{~g} / \mathrm{l} ; p$-aminobenzoic acid $0.2 \mathrm{~g} /$ $\mathrm{l}$; pyridoxine $(\mathrm{HCl}) 0.4 \mathrm{~g} / \mathrm{l}$; riboflavin $0.2 \mathrm{~g} / \mathrm{l}$; thiamine $(\mathrm{HCl}) 0.4 \mathrm{~g} / \mathrm{l}$; Inositol $2 \mathrm{~g} / \mathrm{l}$ ) and $1 \mathrm{ml} / \mathrm{l}$ of $1000 \times$ micronutrients solution (boric acid $0.05 \mathrm{~g} / \mathrm{l}$; copper sulphate $0.004 \mathrm{~g} / \mathrm{l}$; potassium iodide $0.01 \mathrm{~g} / \mathrm{l}$; ferric chloride $0.02 \mathrm{~g} / \mathrm{l}$; manganessium sulphate $0.04 \mathrm{~g} / \mathrm{l}$; sodium molybdate $0.02 \mathrm{~g} / \mathrm{l}$; zinc sulphate $0.04 \mathrm{~g} / \mathrm{l}$ ).

\subsection{Amplification of rabies G-protein gene by RT-PCR}

Viral RNA was isolated using TRIzol ${ }^{\circledR}$ (Invitrogen). Reverse transcription was carried out using $1 \mu \mathrm{g}$ of RNA, random hexamer primers, RNAsin ${ }^{\circledR}$ (Promega), and Moloney Murine Leukemia virus reverse transcriptase (Promega, USA). PCR on the cDNA was performed with GRVF (5' ATGTCGACAAAAGAATGGTTCCTCAGGCTCTCCTGTTTGTACC $\left.3^{\prime}\right)$ and GRVR (5' ATGAATTCTCACAGTCCGGTCTCACCCCCGCTCTTG $3^{\prime}$ ) containing a Sall and EcoRI sites, respectively. PCR was for 30 cycles $\left(94^{\circ} \mathrm{C}\right.$ for $45^{\prime \prime}, 58^{\circ} \mathrm{C}$ for $45^{\prime \prime}$ and $72^{\circ} \mathrm{C}$ for $1.5 \mathrm{~min}$ ). Electrophoresis was in $1.5 \%$ agarose with ethidium bromide.

\subsection{Generation of a recombinant $P$. pastoris}

The purified RT-PCR product was digested with Sall and EcoRI and ligated to the pPIC9 vector using Xhol and EcoRI restriction sites. E.coli TOP10' competent cells were transformed by electroporation with the pPIC9 and the G-protein open reading frame (ORF) insert to create the pPIC9-G expression vector. Transformation was confirmed by colony-PCR using specific primers to the AOX1 region: 5'AOX1 (5' GAC TGG TTC CAA TTG ACA AGC 3') and $3^{\prime}$ AOX1 (5' GCA AAT GGC ATT CTG ACA TCC $3^{\prime}$ ).

For the electroporation, $10 \mu \mathrm{g}$ of pPIC9-G plasmid DNA was digested in the AOX1 promoter with Sacl and used to transform $40 \mu \mathrm{l}$ of the $P$. pastoris competent cells $\left(1 \times 10^{9}\right.$ cells $\left./ \mathrm{ml}\right)$. Recombinant $\mathrm{His}^{+}$colonies were selected on MD plates (without histidine) for $48 \mathrm{~h}$ at $28^{\circ} \mathrm{C}$.

Colony-PCR was performed using the AOX1 primers. The PCR sequence was compared to the rabies $\mathrm{G}$-protein sequence of the CVS strain (GenBank).

\subsection{Small scale protein expression}

PCR positive clones were cultured overnight at $28^{\circ} \mathrm{C}, 100 \mathrm{rpm}$ in $5 \mathrm{ml}$ of YPD medium. Cells were collected by centrifugation $(2000 \mathrm{~g}$, $15 \mathrm{~min}$ ) and resuspended in $50 \mathrm{fml}$ of BMG in a $250 \mathrm{ml}$ Erlenmeyer flask for an additional $24 \mathrm{~h}$. These cells were similarly resuspended in $10 \mathrm{ml}$ of BMM in a $100 \mathrm{ml}$ Erlenmeyer flask for growth under the same conditions for $72 \mathrm{~h}$. Methanol was added every $24 \mathrm{~h}$ to a final concentration of $0.5 \%(\mathrm{v} / \mathrm{v})$. Non-transformed $P$. pastoris was also cultured under similar conditions in BMG/BMM mediums supplemented with histidine, and used as a negative control. Supernatant samples were taken every $24 \mathrm{~h}(0,24,48$ and 72$)$ and then analyzed by SDS-PAGE and ELISA.

\subsection{Detection of recombinant G-protein by ELISA}

Culture supernatant protein from different time-points and cultures were coated in a 96-well plate by mixing $100 \mu \mathrm{l}$ of sample with $100 \mu$ l of coating buffer ( $25 \mathrm{mM} \mathrm{Na}_{2} \mathrm{CO}_{3}, \mathrm{NaHCO}_{3}, \mathrm{pH} 9.6$ ) and incubated at $4{ }^{\circ} \mathrm{C}$ overnight. Then, the plate was blocked at $37^{\circ} \mathrm{C}$ for $1 \mathrm{~h}$ with a blocking buffer containing $3 \%$ of skimmed milk powder in $0.05 \%$ PBS-Tween followed by three washings with $0.05 \%$ PBSTween.

As primary antibody, a 1:500 dilution of a monoclonal antibody to the rabies G-protein (Santa Cruz cat. sc-57995) was added and the samples were incubated at $37^{\circ} \mathrm{C}$ for $1 \mathrm{~h}$. The plate was washed three times. Then a 1:2000 dilution of an Anti-Mouse IgG Peroxidase conjugated antibody produced in rabbit (Sigma cat. A9044) was added and the samples were incubated at $37^{\circ} \mathrm{C}$ for $1 \mathrm{~h}$. Finally, the plate was washed three times and treated with a solution containing $0.03 \%$ of ATBS and $0.02 \%$ of $\mathrm{H}_{2} \mathrm{O}_{2}$ for $1 \mathrm{~h}$ in the dark before measuring the absorbance at $405 \mathrm{~nm}$.

\subsection{High cell density fermentation}

Batch and fed-batch cultures were performed in a 7.5 L BioFlo 310 Benchtop Bioreactor (New Brunswick-Scientific, Edison, NJ, USA).

A starter culture $(150 \mathrm{ml})$ of a SM medium was inoculated with $5 \mathrm{ml}$ of an overnight culture in YPD medium of the selected clone, and incubated at $28{ }^{\circ} \mathrm{C}$ overnight. $3.85 \mathrm{~L}$ of fresh $\mathrm{SM}$ in the fermentor was inoculated with $150 \mathrm{ml}$ of a SM starter culture $\left(\mathrm{OD}_{600 \mathrm{~nm}}=10\right)$. An optical density of 1 unit corresponds to approximately $0,24 \mathrm{~g} / \mathrm{l}$ of dry cell. The temperature was set at $28^{\circ} \mathrm{C}$, and the $\mathrm{pH}$ was adjusted to 5 .

The propeller rate was set to increase to maintain the dissolved oxygen (DO) in $40 \%$ of the saturation value during the glycerol batch. Once glycerol depleted, a methanol feeding strategy was designed to maintain $\sim 40 \%$ DO automatically with a controller regulating the methanol feed rate (BioCommand software, New Brunswick). For $48 \mathrm{~h}$ of methanol induction, the feed pump was set 
to be activated if dissolved oxygen exceeded $42 \%$, and to be stopped if oxygen fell below 38\%. Samples were taken every $12 \mathrm{~h}$ and analyzed by SDS-PAGE and western blot.

Cell dry weight was measured by centrifuging a $10 \mathrm{ml}$ sample at $10,000 \mathrm{~g}$ for $5 \mathrm{~min}$ discarding the upper clear broth. The cells were washed three times with $10 \mathrm{ml}$ of distilled water followed by centrifuging at $10,000 \mathrm{~g}$ for 5 min discarding the upper liquid. Then, the preweighted centrifuge tube containing yeast slurry was dried in an oven overnight at $90{ }^{\circ} \mathrm{C}$. Finally the difference in weight was calculated and the dry weight was expressed in $\mathrm{g} / \mathrm{l}$.

\subsection{SDS-PAGE and western blot assays}

Samples were mixed with reducing sample buffer and separated by $8 \%$ SDS-PAGE gel, before staining with Colloidal Coomassie Brilliant Blue G-250 (Sigma). Bovine Serum Albumin (BSA, at $10-80 \mu \mathrm{g} / \mathrm{ml}$ ) was used to estimate the amount of G-protein during PAGE (TotalLab software).

Western blot samples were separated by SDS-PAGE and transferred to a polyvinylidene difluoride (PVDF) membrane (Millipore). The membrane was blocked overnight at $4{ }^{\circ} \mathrm{C}(5 \%$ of skimmed milk powder in $0.1 \%$ PBS-Tween). After being washed $3 \times 5 \mathrm{~min}(0.1 \%$ PBS-Tween), the membrane was incubated for $1 \mathrm{~h}$ with a 1:200 dilution of a anti-rabies polyclonal antibody produced in rabbit by us, with an immunization protocol at days 0,7 and 14 , using an inactivated vaccine produced in suckling mouse brain (Zoonosis Institute Luis Pasteur of Argentina), and subsequent bleeding at day 21. After three washings, the membrane was incubated for $1 \mathrm{~h}$ with a 1:1000 dilution of an Anti-Mouse IgG - Peroxidase conjugated produced in goat (Sigma cat. A0545). After being washed three times, the bound antibody was detected using a solution containing 3, 3'-diaminobenzidine (DAB) and hydrogen peroxide. In the same way and according to the protocol suggested by the manufacturer, a sample of the culture supernatant was analyzed by western blot after the treatment with the enzyme EndoH (New England Biolabs cat. P0702S) to evaluate the glycosylation of the recombinant protein. For this assay, an anti-G-protein monoclonal antibody produced by the cell culture laboratory of National University of Litoral was used.

\section{Results}

\subsection{RT-PCR and generation of a recombinant P. pastoris}

The G-protein was amplified by RT-PCR, cloned into pPIC9 before sequence analysis of the $1597 \mathrm{bp}$ ORF (Fig. 1). Comparison to the Genbank sequence (accession no. JX944575) a homology superior to $99 \%$ was found and 4 coding differences resulting in V5A, L10P, E408K and R523G were identified (Fig. 2). Electroporation of SacI linearized pPIC9-G into GS115 Pichia cells generated more than 100 clones on minimal plates without histidine.

\subsection{Small scale protein expression and detection by ELISA and SDS- PAGE}

Supernatants of shake flask cultures from fifteen colony-PCR positive clones were screened by ELISA in order to evaluate the expression level. The absorbance values of only four supernatants doubled that of the negative control and were selected for an SDSPAGE. The number four clone (PPRG\#4) was selected for fermentation analysis because it was the only one that generated a band between 55 and $70 \mathrm{kDa}$ when supernatant was analyzed by PAGECoomassie, as in Fig. 4A.

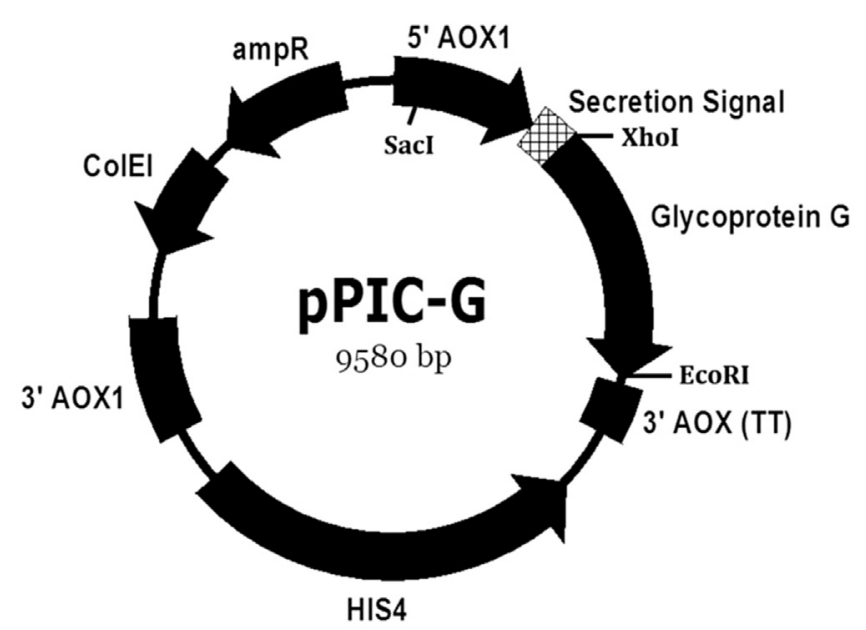

Fig. 1. Plasmid structure of pPIC9-G. 5' AOX1, alcohol oxidase 1 promoter; Secretion signal, $\alpha$-Factor secretion signal; $3^{\prime}$ AOX (TT), transcriptional terminator from $P$. pastoris AOX1 gene; HIS4, gene for selection; ColEI, origin of replication of colicin E1 plasmid DNA; ampR, Ampicillin resistance gene; XhoI and EcoRI cloning sites; Sacl site.

\subsection{High cell density fermentation: Western blot and protein quantification by SDS-PAGE}

Fermentation of clone PPRG\#4 was performed with the described DO-stat method. Cell densities of PPRG\#4 were calculated both for batch and fed-batch. The growth yields obtained were $0.634 \mathrm{~g}$ dry cells/g glycerol and $0.073 \mathrm{~g}$ dry cells/g methanol.

Using this feeding strategy, it was possible to maintain the level of dissolved oxygen around $40 \%$ of saturation (Fig. 3 ). The dry cell weight in culture reached $44.92 \mathrm{~g} / \mathrm{l}$. The initial specific growth rates were $0.258 \mathrm{~h}^{-1}$ and $0.027 \mathrm{~h}^{-1}$ in glycerol and methanol, respectively.

In the SDS-PAGE assay, a band at $48 \mathrm{~h}$ of induction between 55 and $70 \mathrm{kDa}$ was clearly visible in the culture supernatant of PPRG\#4 (Fig. 4A). Using TotalLab software, the G-protein concentration and the molecular size were estimated in $10 \mathrm{mg} / \mathrm{l}$ and $65 \mathrm{kDa}$ respectively. A similar sized band was recognized by anti-G-Protein antibodies in a western blot assay (Fig. 4B). The mobility differences caused by glycans were analyzed by treatment with endo $\mathrm{H}$ and subsequent analysis by western bolt (Fig. 4C). G-protein has 4 predicted N-linked glycosylation sites, and an increased mobility in SDS-PAGE was evident after the Endo $H$ treatment.

\section{Discussion}

Rabies is a worldwide disease which mainly affects developing countries. Thus, an efficient and affordable solution is needed. In order to control and eradicate rabies, it is necessary to study new methodologies for protein production and a quick diagnosis.

We evaluated the production of rabies virus G-protein in P. pastoris to assess the benefit of using a DO-stat fed batch fermentation in high density cultures.

The rabies G-protein gene was cloned in $P$. pastoris and sequenced using specific primers to the G-protein gene. Sequence comparison to the published GenBank accession number JX944575 showed over $99 \%$ of homology and identified 4 differences; none affected the $\mathrm{N}$-linked glycosylation sites described by Wiktor et al. [10]. This is of particular interest since non-glycosylated G-protein does not provide protective immunity [24,25]; although it still remains to be see if glycosylation in the yeast will substitute for mammalian glycosylation and support immunity.

Using $P$. pastoris as the expression system, the dissolved oxygen 
1

ATGAGATTTCCTTCAATTTTTACTGCAGTTTTATTCGCAGCATCCTCCGCATTAGCTGCTCCAGTCAACACTACAACAGAAGATGAAACGGCACAAATT $\begin{array}{llllllllllllllllllllllllllllllllll}\text { M } & \text { R } & \text { F } & \text { P } & \text { S } & \text { I } & \text { F } & \text { T } & \text { A } & \text { V } & \text { L } & \text { F } & \text { A } & \text { A } & \text { S } & \text { S } & \text { A } & \text { L } & \text { A } & \text { A } & \text { P } & \text { V } & \text { N } & \text { T } & \text { T } & \text { T } & \text { E } & \text { D } & \text { E } & \text { T } & \text { A } & Q & \text { I } & \text { I }\end{array}$ 100 CCGGCTGAAGCTGTCATCGGTTACTCAGATTTAGAAGGGGATTTCGATGTTGCTGTTTTGCCATTTTCCAACAGCACAAATAACGGGTTATTGTTTATA \begin{tabular}{lllllllllllllllllllllllllllllllllllll}
\hline P & A & E & A & V & I & G & Y & S & D & L & E & G & D & F & D & V & A & V & L & P & F & S & N & S & T & N & N & G & L & L & F & I
\end{tabular}

AATACTACTATTGCCAGCATTGCTGCTAAAGAAGAAGGGGTATCTCTCGACAAAAGAATGGTTCCTCAGGCTCTCCTGTTTGTACCCCTTCTGGGTTTT

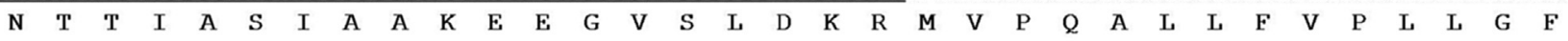

298 TCGTTGTGTTTCGGGAAGTTCCCCATTTACACGATACCAGACGAACTTGGTCCCTGGAGCCCTATTGACATACACCATCTCAGCTGTCCAAATAACCTG

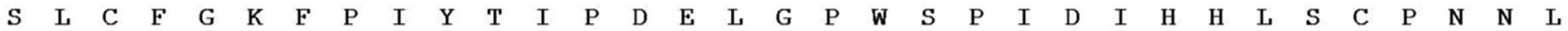

397 GTTGTGGAGGATGAAGGATGTACCAACCTGTCCGAGTTCTCCTACATGGAACTCAAAGTGGGATACATCTCAGCCATCAAAGTGAACGGGTTCACTTGC

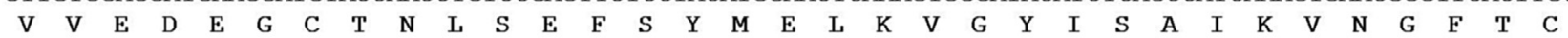

ACAGGTGTTGTGACAGAGGCAGAGACCTACACCAACTTTGTTGGTTATGTCACAACCACATTCAAGAGAAAGCATTTCCGCCCCACCCCAGACGCATGT

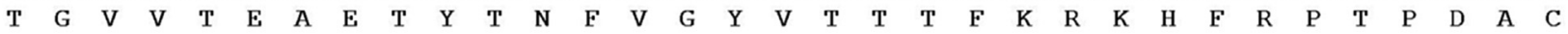

AGAGCCGCGTATAACTGGAAGATGGCCGGTGACCCCAGATATGAAGAGTCCCTACACAATCCATACCCCGACTACCACTGGCTTCGAACTGTAAGAACC $\begin{array}{llllllllllllllllllllllllllllllllllll}R & \text { A } & \text { A } & \text { Y } & \text { N } & \text { W } & \text { K } & \text { M } & \text { A } & \text { G } & \text { D } & \text { P } & \text { R } & \text { Y } & \text { E } & \text { E } & \text { S } & \text { L } & \text { H } & \text { N } & \text { P } & \text { Y } & \text { P } & \text { D } & \text { Y } & \text { H } & \text { W } & \text { L } & \text { R } & \text { T } & \text { V } & \text { R } & \text { T }\end{array}$

ACCAAAGAGTCCCTCATTATCATATCCCCAAGTGTGACAGATTTGGACCCATATGACAAATCCCTTCACTCAAGGGTCTTCCCTGGCGGAAAGTGCTCA $\begin{array}{llllllllllllllllllllllllllllllllllll}\mathrm{T} & \mathrm{K} & \mathrm{E} & \mathrm{S} & \mathrm{L} & \mathrm{I} & \mathrm{I} & \mathrm{I} & \mathrm{S} & \mathrm{P} & \mathrm{S} & \mathrm{V} & \mathrm{T} & \mathrm{D} & \mathrm{L} & \mathrm{D} & \mathrm{P} & \mathrm{Y} & \mathrm{D} & \mathrm{K} & \mathrm{S} & \mathrm{L} & \mathrm{H} & \mathrm{S} & \mathrm{R} & \mathrm{V} & \mathrm{F} & \mathrm{P} & \mathrm{G} & \mathrm{G} & \mathrm{K} & \mathrm{C} & \mathrm{S}\end{array}$

793 GGAATAACGGTGTCCTCTACCTACTGCTCAACTAACCATGATTACACCATTTGGATGCCCGAGAATCCGAGACCAAGGACACCTTGTGACATT'TTACC

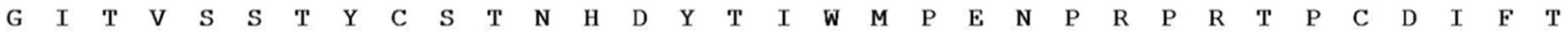

AATAGCAGAGGGAAGAGAGCATCCAACGGGAACAAGACTTGCGGCTTTGTGGATGAAAGAGGCCTGTATAAGTCTCTAAAAGGAGCATGCAGGCTCAAG

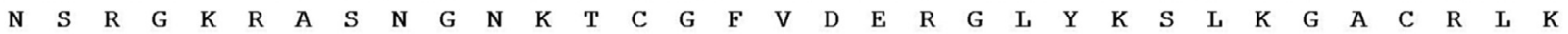

991 TTATGTGGAGTTCTTGGACTTAGACTTATGGATGGAACATGGGTCGCGATGCAAACATCAGATGAGACCAAATGGTGCCCTCCAGATCAGTTGGTGAAT

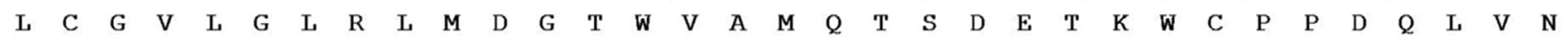

1090 TTGCACGACTTTCGCTCAGACGAGATTGAGCATCTCGTTGTGGAGGAGTTAGTCAAGAAAAGAGAGGAATGTCTGGATGCATTAGAGTCCATCATGACC

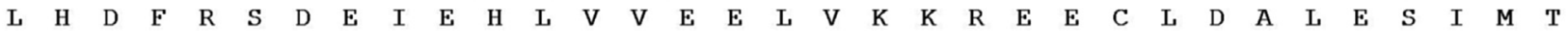

1189 ACCAAGTCAGTAAGTTTCAGACGTCTCAGTCACCTGAGAAAACTTGTCCCAGGGTTTGGAAAAGCATATACCATATTCAACAAAACCTTGATGGAGGCT $\begin{array}{llllllllllllllllllllllllllllllllllll}\mathrm{T} & \mathrm{K} & \mathrm{S} & \mathrm{V} & \mathrm{S} & \mathrm{F} & \mathrm{R} & \mathrm{R} & \mathrm{L} & \mathrm{S} & \mathrm{H} & \mathrm{L} & \mathrm{R} & \mathrm{K} & \mathrm{L} & \mathrm{V} & \mathrm{P} & \mathrm{G} & \mathrm{F} & \mathrm{G} & \mathrm{K} & \mathrm{A} & \mathrm{Y} & \mathrm{T} & \mathrm{I} & \mathrm{F} & \mathrm{N} & \mathrm{K} & \mathrm{T} & \mathrm{L} & \mathrm{M} & \mathrm{E} & \mathrm{A}\end{array}$

1288 GATGCTCACTACAAGTCAGTCCGGACCTGGAATGAGATCATCCCCTCAAAAGGGTGTTTGAAAGTTGGAGGAAGGTGCCATCCTCATGTGAACGGGGTG

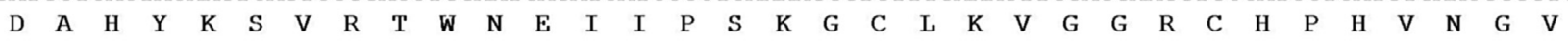

1387 TTTTTCAATGGTATAATATTAGGGCCTGACGACCATGTCCTAATCCCAGAGATGCAATCATCCCTCCTCCAGCAACATATGGAGTTGTTGAAATCTTCA

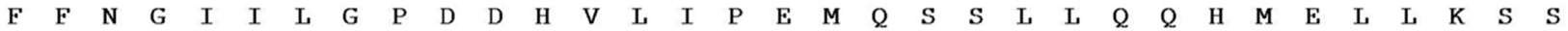

1486 GTTATCCCCCTGATGCACCCCCTGGCAGACCCTTCTACAGTTTTCAAAGAAGGTGATGAGGCTGAGGATTTTGTTGAAGTTCACCTCCCCGATGTGTAC

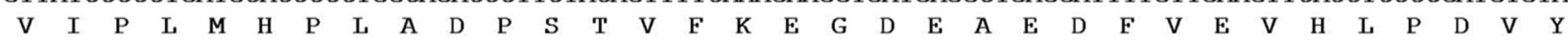

1585 AAACAGATCTCAGGGGTTGACCTGGGTCTCCCGAACTGGGGAAAGTATGTATTGATGACTGCAGGGGCCATGATTGGCCTGGTGTTGATATTTTCCCTA

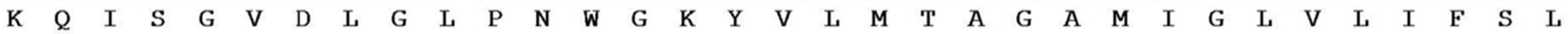

1684 ATGACATGGTGCAGAAGAGCCAATCGACCAGAATCGAAACAACGCAGTTTTGGAGGGACAGGGGGGAATGTGTCAGTCACTTCCCAAAGCGGAAAAGTC

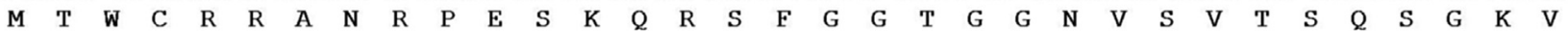

1783 ATACCTTCATGGGAATCATACAAGAGCGGGGGTGAGACCGGACTGTGAGAATTC

$\begin{array}{llllllllllllllll}I & P & S & W & E & S & Y & K & S & G & G & E & T & G & L & *\end{array}$

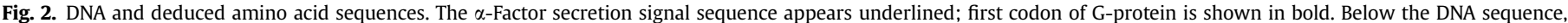
deduced amino acid sequence is described.

and methanol concentration in the culture medium during feeding are the most important parameters for efficient protein expression [23]. Mut $^{+}$strains of $P$. pastoris are sensitive to high residual methanol concentrations [35]. When there is excess of oxygen and methanol, formaldehyde, the first product of methanol metabolism, rises to toxic levels due to its accumulation as a product of the incomplete oxidation of methanol [35-38]. Thus, for successful cell growth and protein expression with Mut ${ }^{+}$strains, it is critical to maintain a low methanol concentration in the bioreactor. The advantage of $\mathrm{Mut}^{+}$strains for protein expression in relation to AOX- defective strains is their considerably faster methanol growth rate. However, the concentration of methanol must be tightly controlled. In order to decrease proteolytic degradation, improve protein expression, and avoid anaerobic fermentation, a DO-stat fed batch strategy was used to ensure a minimum concentration of methanol and an adequate level of oxygen. Under these controlled conditions, a high density culture was performed.

Due to the high cell density reached in P. pastoris cultures, oxygen transfer limitation is relatively common in the cultivation processes. The DO-stat feeding control proposed in this work 


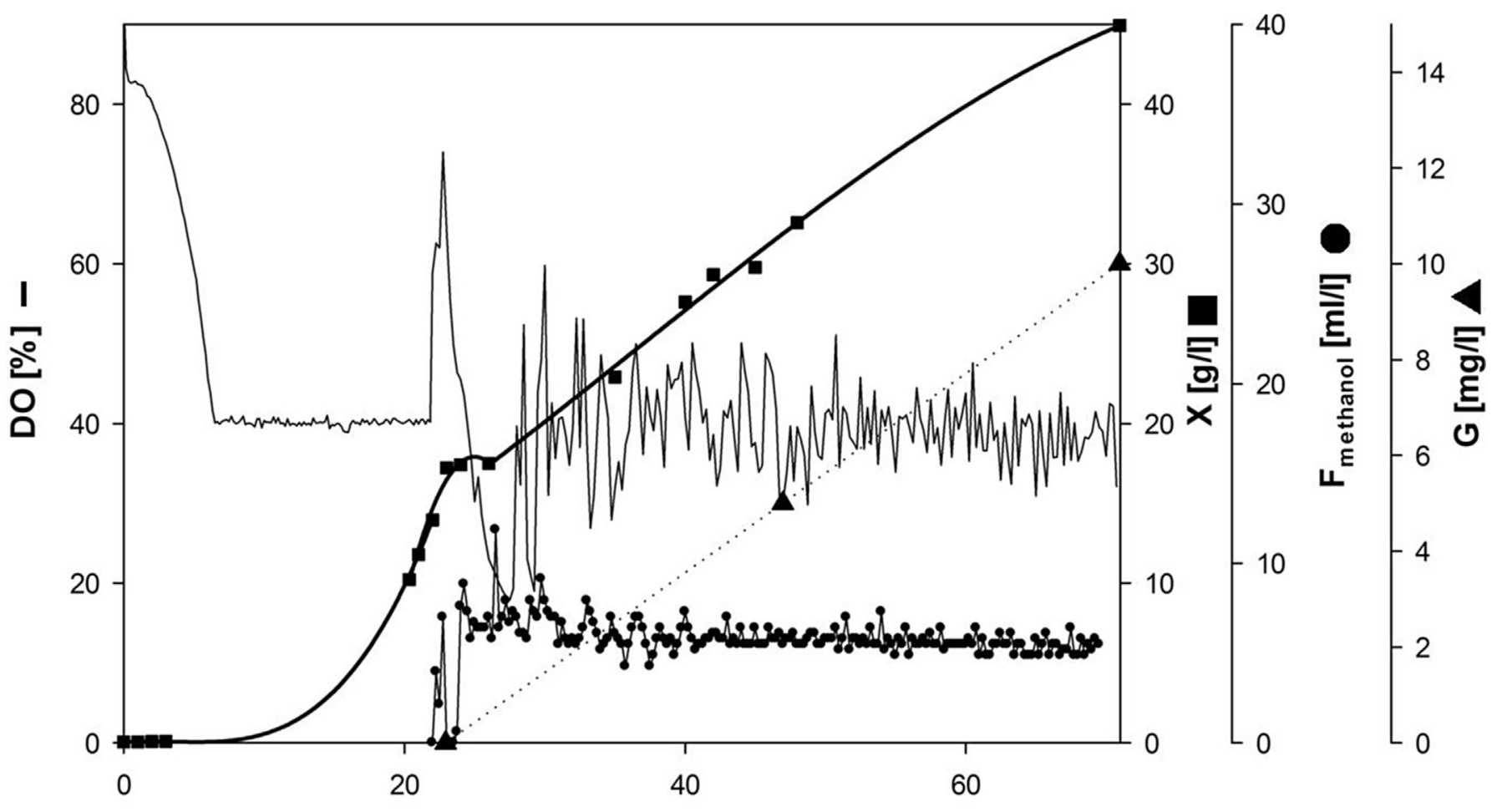

Time [h]

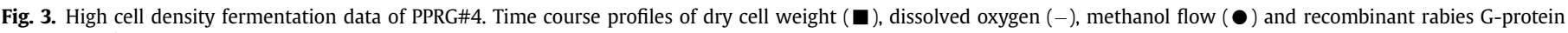
expressed ( $\mathbf{\Delta}$ ) in fed-batch culture with the DO-stat method. The methanol fed-batch induction was initiated at $22 \mathrm{~h}$ and the DO was controlled around $40 \%$.

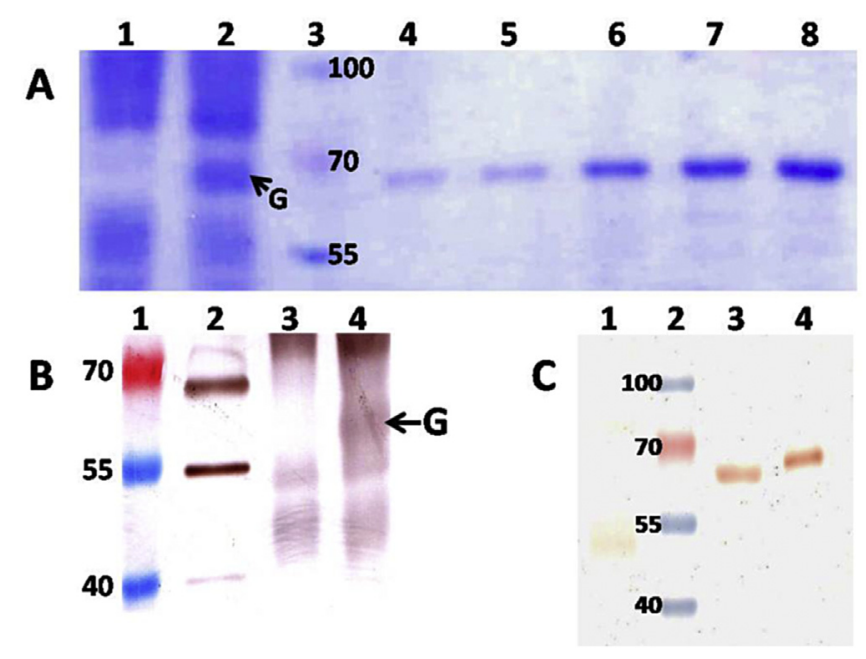

Fig. 4. PAGE analysis. A. Coomassie brilliant blue stained. Four times concentrated culture supernatants $(10 \mu \mathrm{l})$ from $48 \mathrm{~h}$ post methanol induction: lane 1 , nontransformed P. pastoris (negative control); lane 2, PPRG\#4; lane 3, prestained molecular weight markers (cat. 26616, Fermentas); lanes 4-8, 100, 200, 400, 600, $800 \mathrm{ng}$ of BSA. B. Western blot using an anti-rabies polyclonal antibody. Lane 1: prestained molecular weight markers (cat. 26616, Fermentas); lane 2: $10 \mu \mathrm{l}$ of inactivated vaccine (VERORAB - SANOFI PASTEUR); the upper band is the G-protein and the band at about $55 \mathrm{kDa}$ is the nucleoprotein of rabies virus; lane 3: non-transformed P. pastoris (negative control), Lane 4: PPRG\#4. C. Western blot with EndoH treatment using an anti-G-protein monoclonal antibody. Lane 1, non-transformed P. pastoris (negative control); lane 2, prestained molecular weight markers (cat. 26616, Fermentas); lane 3, recombinant rabies G-protein EndoH-digested; lane 4, recombinant rabies G-protein not digested. (For interpretation of the references to colour in this figure legend, the reader is referred to the web version of this article.) maximizes methanol feeding rate by regulating DO level to a constant set-point (40\%). In this way, it was possible to increase the concentration of biomass and the expression of the recombinant protein without oxygen transfer limitation or the accumulation of toxic levels of methanol. In conclusion, the DO-stat method developed in this study might be effective as a method for substrate feeding in high cell density cultures.

Although the growth yield in methanol and G-protein production level are not high when compared with similar works (Table 1), it is interesting to note that only $24 \mathrm{~h}$ of induction were necessary to detect the recombinant G-protein produced. Moreover, proteolytic degradation was not observed at $48 \mathrm{~h}$. G-protein production level achieved by Nagesha et al. [33] is higher than the one we achieved. However, their incubation period (108 h) was considerably longer than ours and they described total proteolysis after $12 \mathrm{~h}$. One of the main causes of proteolysis in P. pastoris is methanol accumulation in an environment without oxygen. In our opinion, this could be avoided by using a controlled feeding strategy as described in this work. Ben Azoun et al. [34,35] did not comment on proteolytic degradation in their work; however, the reported levels were also 7 times lower than reported here.

The molecular size of the glycosylated recombinant G-protein was estimated to be approximately $65 \mathrm{kDa}$ and coincides with the native rabies virus $\mathrm{G}$-protein as described in previous manuscripts [39]. Like native G-protein, the recombinant G-protein was specifically recognized by anti rabies virus antibodies in western blot assays.

These results showed that under the tested culture conditions, a suitable expression of rabies G-protein can be achieved after a short induction time and without proteolytic degradation. This strategy allows culture time reduction and minimizes the cost of production which is important for industrial applications. 
Table 1

Comparison of recombinant rabies G-proteins produced in different expression systems (bacteria, plant, insect, mammalian and yeast).

\begin{tabular}{|c|c|c|c|c|c|}
\hline System & Expression level & Secreted & Induction Time & Observation & Reference \\
\hline \multicolumn{6}{|l|}{ Bacteria } \\
\hline Escherichia coli & $5.75 \mathrm{mg} / \mathrm{l}^{\mathrm{a}}$ & No & $6 \mathrm{~h}$ & Non glycosylated & Singh et al. [26] \\
\hline Escherichia coli & $3 \%$ & No & $\mathrm{N} / \mathrm{D}$ & Non glycosylated, insoluble & Y elverton et al. [22] \\
\hline \multicolumn{6}{|l|}{ Plant } \\
\hline Nicotiana tabacum & $0.015-0.38 \%^{\mathrm{c}}$ & No & $\mathrm{N} / \mathrm{D}$ & Comlicated purification & Y adav et al. [27] \\
\hline Nicotiana tabacum & $0.38 \%$ & No & $\mathrm{N} / \mathrm{D}$ & Comlicated purification & Ashraf et al. [28] \\
\hline \multicolumn{6}{|l|}{ Insert cells } \\
\hline Drosophila melanogaster & $39.7 \mu \mathrm{g} / \mathrm{l}^{\mathrm{a}}$ & No & $10 \mathrm{~d}$ & Low expression level & Batista et al. [29] \\
\hline Drosophila melanogaster & $3 \mathrm{mg} / \mathrm{l}^{\mathrm{a}}$ & No & $120 \mathrm{~h}$ & Low expression level & Ventini et al. [30] \\
\hline \multicolumn{6}{|l|}{ Mammalian cells } \\
\hline $\begin{array}{l}\text { Madin Darby bovine kidney } \\
\text { Yeast }\end{array}$ & $30 \mathrm{mg} / \mathrm{l}^{\mathrm{d}}$ & Yes & $21 \mathrm{~d}$ & Long culture time & Gupta et al. [31] \\
\hline Hansenula polymorpha & $14.6 \mathrm{mg} / \mathrm{l}^{\mathrm{d}}$ & Yes & $72 \mathrm{~h}$ & Truncated glycoprotein & Qian et al. [32] \\
\hline Pichia pastoris & $200 \mathrm{mg} / \mathrm{l}^{\mathrm{d}}$ & Yes & $108 \mathrm{~h}$ & Proteolytic degradation & Nagesha et al. [33] \\
\hline Pichia pastoris & $1.23 \mathrm{mg} / \mathrm{l}^{\mathrm{d}}$ & Yes & $72 \mathrm{~h}$ & Low expression level & Azoun et al. [34] \\
\hline Pichia pastoris & $10 \mathrm{mg} / \mathrm{l}^{\mathrm{d}}$ & Yes & $48 \mathrm{~h}$ & & This work \\
\hline
\end{tabular}

${ }^{\text {a }} \mathrm{G}$-protein present in cell lysate.

b Grams of G-protein every $100 \mathrm{~g}$ of intracellular protein total.

c Grams of G-protein every $100 \mathrm{~g}$ of leaf protein total.

d G-protein present in culture supernatant. N/D indicates no data found.

Higher levels of G-protein production may be possible with more bioprocess optimization, such as with a focus on: longer induction times, an exponential fed-batch culture and pure oxygen administration. Almost no degradation was evident in G-protein production after $48 \mathrm{~h}$ induction in this work. Further studies will be necessary to determine if the protein is immunogenic in animal models and if it can be used as an antigen in the development of diagnostic kits. Such better production methods of the G-protein will be helpful in the control and eradication of this zoonotic disease.

\section{References}

[1] K. Hampson, L. Coudeville, T. Lembo, M. Sambo, A. Kieffer, M. Attlan, et al. Estimating the global burden of endemic canine rabies, PLoS Negl. Trop. Dis. 9 (4) (2015) e0003709.

[2] F.X. Meslin, D.B. Fishbein, H.C. Matter, Rationale and prospects for rabies elimination in developing countries, Curr. Top. Microbiol. Immunol. 187 (1994) 1-26.

[3] L. Martinez, Global infectious disease surveillance, Int. J. Infect. Dis. 4 (4) (2000) 222-228.

[4] A. Belotto, L.F. Leanes, M.C. Schneider, H. Tamayo, E. Correa, Overview of rabies in the Americas, Virus Res. 111 (1) (2005) 5-12.

[5] R. Franka, T.G. Smith, J.L. Dyer, X. Wu, M. Niezgoda, C.E. Rupprecht, Current and future tools for global canine rabies elimination, Antivir. Res. 100 (1) (2013) 220-225.

[6] G.D. Coslett, B.P. Holloway, J.F. Obijeski, The structural proteins of rabies virus and evidence for their synthesis from separate monocistronic RNA species, J. Gen. Virol. 49 (1) (1980) 161-180.

[7] K.K. Conzelmann, J.H. Cox, L.G. Schneider, H.J. Thiel, Molecular cloning and complete nucleotide sequence of the attenuated rabies virus SAD B19, Virology 175 (2) (1990) 485-499.

[8] Y. Gaudin, R.W. Ruigrok, C. Tuffereau, M. Knossow, A. Flamand, Rabies virus glycoprotein is a trimer, Virology 187 (2) (1992) 627-632.

[9] M.A. Whitt, L. Buonocore, C. Prehaud, J.K. Rose, Membrane-Fusion activity, oligomerization, and assembly of the rabies virus glycoprotein, Virology 185 (2) (1991) 681-688.

[10] T.J. Wiktor, E. György, D. Schlumberger, F. Sokol, H. Koprowski, Antigenic properties of rabies virus components, J. Immunol. 110 (1) (1973) 269-276.

[11] J.H. Cox, B. Dietzschold, L.G. Schneider, Rabies virus glycoprotein. II. Biological and serological characterization, Infect. Immun. 16 (3) (1977) 754-759.

[12] P. Perrin, L. Thibodeau, P. Sureau, Rabies immunosome (subunit vaccine) structure and immunogenicity. Pre- and post-exposure protection studies, Vaccine 3 (3) (1985) 325-332.

[13] R.I. Macfarlan, B. Dietzschold, H. Koprowski, Stimulation of cytotoxic Tlymphocyte responses by rabies virus glycoprotein and identification of an immunodominant domain, Mol. Immunol. 23 (7) (1986) 733-741.

[14] E. Celis, R.W. Karr, B. Dietzschold, W.H. Wunner, H. Koprowski, Genetic restriction and fine specificity of human $\mathrm{T}$ cell clones reactive with rabies virus, J. Immunol. 141 (8) (1988) 2721-2728.

[15] H.D. Foley, J.P. McGettigan, C.A. Siler, B. Dietzschold, M.J. Schnell, A recombinant rabies virus expressing vesicular stomatitis virus glycoprotein fails to protect against rabies virus infection, Proc. Natl. Acad. Sci. U. S. A. 97 (26) (2000) 14680-14685.

[16] B. Dietzschold, J.H. Cox, G. Schneider, Structure and function of rabies virus glycoprotein, Dev. Biol. Stand 40 (1978) 45-55.

[17] F. Sokol, D. Stancek, H. Koprowski, Structural proteins of rabies virus, J. Virol. 7 (2) (1971) 241-249.

[18] E. Fuenzalida, Laboratory techniques in rabies: suckling mouse brain vaccine, Monogr. Ser. World Health Organ 23 (1973) 216-220.

[19] H.S. Swamy, S.K. Shankar, P.S. Chandra, S.R. Aroor, A.S. Krishna, V.G. Perumal, Neurological complications due to beta-propiolactone (BPL)-inactivated antirabies vaccination. Clinical, electrophysiological and therapeutic aspects, J. Neurol. Sci. 63 (1) (1984) 111-128.

[20] N. Bardiya, Expression in and purification of Hepatitis B surface antigen (Sprotein) from methylotrophic yeast Pichia pastoris, Anaerobe 12 (4) (2006) 194-203.

[21] B. Rombaut, J.P. Jore, Immunogenic, non-infectious polio subviral particles synthesized in Saccharomyces cerevisiae, J. Gen. Virol. 78 (8) (1997) 1829-1832.

[22] S. Macauley-Patrick, M.L. Fazenda, B. McNeil, L.M. Harvey, Heterologous protein production using the Pichia pastoris expression system, Yeast 22 (4) (2005) 249-270.

[23] C.P. Hollenberg, G. Gellissen, Production of recombinant proteins by methylotrophic yeasts, Curr. Opin. Biotechnol. 8 (5) (1997) 554-560.

[24] E. Yelverton, S. Norton, J.F. Obijeski, D.V. Goeddel, Rabies virus glycoprotein analogs: biosynthesis in Escherichia coli, Science 219 (4585) (1983) 614-620.

[25] R.F. Lathe, M.P. Kieny, D. Schmitt, P. Curtis, J.P. Lecocq, M13 bacteriophage vectors for the expression of foreign proteins in Escherichia coli: the rabies glycoprotein, J. Mol. Appl. Genet. 2 (4) (1984) 331-342.

[26] A. Singh, D. Yadav, K. Rai, M. Srivastava, P. Verma, P. Singh, R. Tuli, Enhanced expression of rabies virus surface G-protein in Escherichia coli using SUMO fusion, Protein J. 31 (1) (2012) 68-74.

[27] D. Yadav, S. Ashraf, P. Singh, R. Tuli, Localization of rabies virus glycoprotein into the endoplasmic reticulum produces immunoprotective antigen, Protein J. 31 (6) (2012) 447-456.

[28] S. Ashraf, P. Singh, D. Yadav, M. Shahnawaz, S. Mishra, S. Sawant, R. Tuli, High level expression of surface glycoprotein of rabies virus in tobacco leaves and its immunoprotective activity in mice, J. Biotechnol. 119 (1) (2005) 1-14.

[29] F. Batista, A. Moraes, H. Büntemeyer, T. Noll, Influence of culture conditions on recombinant Drosophila melanogaster S2 cells producing rabies virus glycoprotein cultivated in serum-free medium, Biologicals 37 (2) (2009) 108-118.

[30] D. Ventini, R. Astray, M. Lemos, S. Jorge, C. Riquelme, C. Suazo, A. Tonso, C. Pereira, Recombinant rabies virus glycoprotein synthesis in bioreactor by transfected Drosophila melanogaster S2 cells carrying a constitutive or an inducible promoter, J. Biotechnol. 146 (4) (2010) 169-172.

[31] P. Gupta, S. Sharma, S. Walunj, V. Chaturvedi, A. Raut, S. Patial, A. Rai, K. Pandey, M. Saini, Immunogenic and antigenic properties of recombinant soluble glycoprotein of rabies virus, Vet. Microbiol. 108 (3-4) (2005) 207-214.

[32] W. Qian, F. Aguilar, T. Wang, B. Qiu, Secretion of truncated recombinant rabies virus glycoprotein with preserved antigenic properties using a co-expression system in Hansenula polymorpha, J. Microbiol. 51 (2) (2013) 234-240.

[33] S.N. Nagesha, P.H. Ramanjini Gowda, T.M. Ningaraju, S.N. Madhusudana, N. Deepak, H.M. Mahadeva Swamy, K.N. Yogendra, T. Nagaraju, A.S. Desai, Heterologous expression of CVS rabies virus glycoprotein gene in Pichia pastoris, IJGEB 1 (1) (2010) 101-110.

[34] S. Ben Azoun, M. Ben Zakour, S. Sghaier, H. Kallel, Expression of rabies virus 
glycoprotein in the methylotrophic yeast Pichia pastoris, Microb. Biotechnol. 9 (3) (2016) 355-368.

[35] R. Couderc, J. Barratti, Oxidation of methanol by the yeast Pichia pastoris: purification and properties of alcohol oxidase, Agric. Biol. Chem. 44 (11) (1980) 2279-2289.

[36] J. Swartz, C. Cooney, Methanol inhibition in continuous cultures of Hansenula polymorpha, Appl. Environ. Microbiol. 41 (5) (1981) 1206-1213.
[37] W. Hazeu, R. Donker, A continuous culture study of methanol and formate utilization by the yeast Pichia pastoris, Biotechnol. Lett. 5 (6) (1983) 399-404.

[38] M. Gleeson, P. Sudbery, The methylotrophic yeasts, Yeast 4 (1) (1988) 1-15.

[39] C. Langevin, H. Jaaro, S. Bressanelli, M. Fainzilber, C. Tuffereau, Rabies virus glycoprotein (RVG) is a trimeric ligand for the N-terminal cysteine-rich domain of the mammalian p75 neurotrophin receptor, J. Biol. Chem. 277 (40) (2002) 37655-37662. 